\title{
Lightning Density Distribution and Hazard in an Alpine Region
}

\author{
C. Neuwirth ${ }^{*}$, W. Spitzer and T. Prinz
}

Research Studios Austria - Studio iSpace, Salzburg, Austria

\begin{abstract}
Due to the expected climate change driven increase of extreme weather events, damage risks for infrastructure and buildings are rising. Hence spatial decision-support material is necessary to enhance risk management and planning strategies. The presented study contributes to this topic by means of an analysis of cloud-to-ground lightning patterns and their impact on structural facilities using Geographic Information Systems (GIS). Lightning records from 1998 to 2009 , ascertained by the European Cooperation for Lightning Detection (EUCLID), were utilized in order to apply three different lightning density approaches to an alpine area comprising the Austrian federal province of Salzburg and southeast Bavaria, Germany. Based on the derived lightning density distribution maps and an elevation model, spatial coherences between lightning activity and various topographic properties such as altitude or surface curvature were evaluated. In order to subsequently estimate the lightning hazard to buildings in the city of Salzburg, the frequencies of hazardous lightning events were estimated in GIS using a European lightning protection standard (EN62305-2 Risk Management) as a foundation. Thereby, the prototypical realization was based on the lightning density, a cadastral dataset, and elevation data. The lighting density results obtained show high lightning activity with more than 3 yearly flashes per square kilometer along the northern edge of the Alps. The hazard analysis in the city of Salzburg showed high hazards for buildings due to electromagnetic induction (up to one dangerous event in each year) and comparatively low hazards due to direct lightning strikes (one dangerous event every 10 to 2200 years).
\end{abstract}

Keywords: Altitude, geographic information system (GIS), hazard, lightning density, topography.

\section{INTRODUCTION}

A lightning discharge is a fascinating but also frightening phenomenon. The financial burden caused by damages to electrical devices in Austria, amounts to a multi-digit million euro range per year with an upward trend [1]. For this reason, research is particularly needed for generating largescale knowledge about the spatial distribution of lightning activity and vulnerable structures.

In this article spatial cloud-to-ground lightning activity was analyzed and visualized based on lightning records ascertained by the European Cooperation for Lightning Detection (EUCLID) and provided by ALDIS (Austrian Lightning Detection \& Information System). The crossborder study area covers an area of 40 thousand square kilometers encompassing the Austrian federal province of Salzburg, as well as south-east Bavaria, Germany. From 1998 to 2009 about 1 million cloud-to-ground lightning flashes (CG flashes) occurred in this area, populated by roughly 5 million inhabitants.

CG flashes are spatiotemporal clusters of partial discharges (strokes), already grouped by the Lightning Location System (LLS).

Therefore a perimeter of $10 \mathrm{~km}$ and a timespan of 1.5 seconds are usually used in order to group strokes into flashes $[9,10]$. In order to analyze cloud-to-ground lightning flash activity fine-grain with respect to the spatial distri-

*Address correspondence to this author at the Research Studios iSpace, Research Studios Austria, Forschungsgesellschaft mbH, Schillerstrabe 25, 5020 Salzburg, Austria; Tel: +43 662 908585-211;

E-mail: christian.neuwirth@ researchstudio.at bution of lightning occurrences, a Geographic Information System (GIS) was used for modeling grid-based lightning density surfaces. GIS serves as a tool for storing, analyzing and visualizing spatial datasets.

The spatially explicit approach enables the distinction between areas exhibiting low or high lightning activity (Cold Spots or Hot Spots), and therefore facilitates the locationdependent application of prevention activities. In addition, because of the highly diverse relief, which exhibits large differences in altitude, ranging from 250 to 3400 m.s.l., the effects of topography on the spatial distribution of the lightning activity were evaluated using a SRTM (Shuttle Radar Topography Mission) elevation model, which is a digital representation of the Earth's terrain, provided by USGS (United States Geological Survey).

The derived lightning activity maps could subsequently be used for assessing the frequency of hazardous lightning events to structural facilities. Thereby, a hazardous event is considered as a lightning flash which exhibits potentially harmful effects on buildings. Combined with cadastral data and a more detailed elevation model, provided by the Government of Salzburg, a spatial hazard assessment was drafted.

In this context, a European lightning protection standard (EN62305-2 Risk Management [5]) was utilized for the prototypical implementation of a spatial hazard estimation in GIS. This standard is commonly used for the estimation of lightning risks to single buildings in order to apply appropriate protective measures to them. Consequently, "object-based" data such as building layout or height was necessary. For this purpose, the study area was reduced to the extent of the city of Salzburg, which comprises an area of 
66 square kilometers populated by roughly 150 thousand inhabitants.

The main focus of this approach is the integrative assessment and visualization of large-scale lightning hazards to buildings caused by direct lightning strikes and lightning strikes nearby an object. The results can be used as spatial decision support material for lightning prevention, risk management, spatial planning and civil protection.

\section{METHOD}

\subsection{Modeling Lightning Distribution}

To visualize and compare spatial patterns, lightning flash densities were modeled using a grid file format. This lightning flash density can be defined as the number of flashes of a specific lightning type occurring on or over an area unit in a unit of time [3].

For the calculation of the flash density in the study area, well-known GIS technologies were used to count CG flashes (cf. explanation in chapter 1) per grid cell and time interval. This procedure allowed the derivation of the so-called Local Flash Density (LFD), which represents the number of lightning flashes per raster cell and year. According to Diendorfer [4] the finest appropriate spatial resolution for lightning densities is $1 \mathrm{~km}$. Therefore the statistics grid of Statistics Austria in $1 \mathrm{~km}$ resolution was chosen, to allow the results to be combined with census data in other analyses.

In order to additionally mitigate statistical outliers [4], the LFD (1 km grid) was smoothed using a $3 \times 3$ moving window $(3 \times 3$ grid cells, grid $1 \mathrm{~km})$ in order to calculate a focal mean for each grid cell (see Fig. 1). Thereby, the moving window transits each raster line from left to right and calculates the arithmetic average for the respective cells based on the center cell and the eight surrounding cells. This arithmetically averaged Focal Flash Density (FFD) is commonly used to describe lightning activity and to assess the lightning strike risk for buildings [5].

In addition to these conventional approaches, a third method named Probabilistic Flash Density (PFD) was applied. For the derivation of the PFD, a more complex calculation, following the conception of Campos and Pinto [6] was used.

In contrast to the LFD and FFD, probability ellipses, indicating the location accuracy for each detected lightning flash, were aggregated instead of discrete flash points. In order to enable performant grid aggregation, the continuous probability ellipses were discretized into $10 \%$ probability slices to model the 2-dimensional Gaussian normal distribution. Thus, the PFD could be calculated by the summation of all probability-slice-values per grid cell depending on their grid overlap area (see Fig. 2).

Based on the density model FFD, a cartographic regionalization (Cold Spots and Hot Spots) was derived. Therefore, the FFD, as well as the yearly average FFD was calculated for each single year (1998-2009) for the entire study area. Subsequently, those grid cells were selected, whose yearly FFD was above respectively below the yearly average FFD in each single year. After merging these selected cells the so delimitated Cold Spots or Hot Spots were generalized by means of smoothing algorithms in order to improve cartographic representation and readability. Those grid cells, which are not consistently above or below the average in all years cannot be assumed as Cold Spots or Hot Spots and were therefore not visualized.

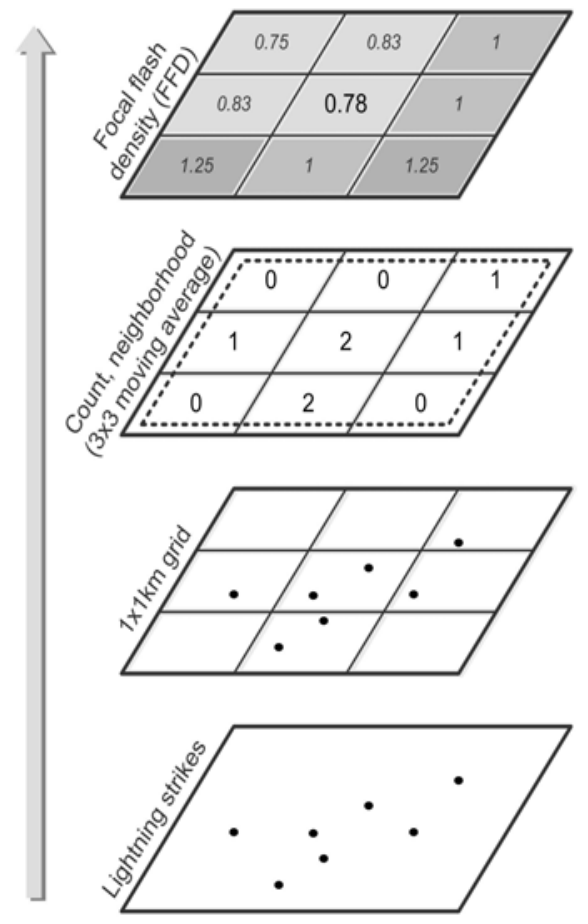

Fig. (1). Estimation of focal flash density (FFD).

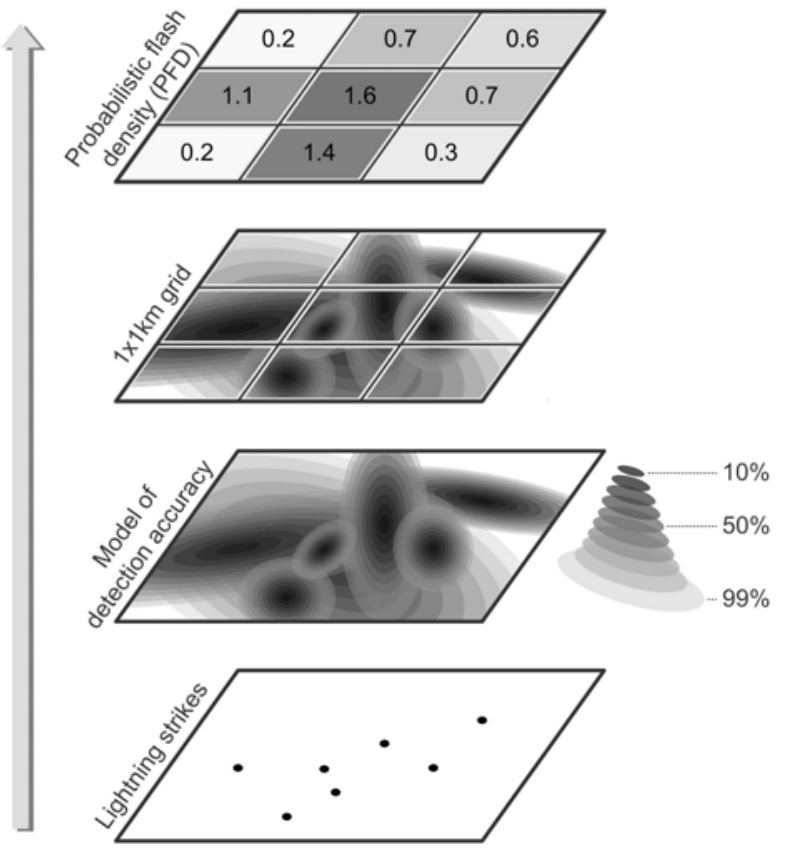

Fig. (2). Estimation of probabilistic flash density (PFD).

Further, the spatial coherences between lightning activity and topographic properties were estimated on a cell by cell basis using a linear ordinary least square regression model. For this purpose, the $1 \mathrm{~km}$ lightning-grid was supplemented 
with further spatial information such as altitude and surface curvature. The surface curvature evaluation implies the classification of the topography into the categories plane, concave and convex. These topographic properties were derived from the SRTM elevation model with a spatial resolution of $90 \mathrm{~m}$ using a 9x9 moving window (9x9 grid cells) to calculate a focal mean for each grid cell. The difference between this smoothened grid and the original elevation model represents an approximation of the surface curvature. Thereby, meaningful results were achieved using thresholds for the difference of $\leq-50$ for concave and $>50$ for convex shapes. Raster cells exhibiting smaller difference values were considered as plane surfaces. Subsequently, altitude and curvature were aggregated to the $1 \mathrm{~km}$ lightninggrid by utilizing an arithmetical average function. Based on this grid, arbitrary sub-territories could be evaluated independently in order to compare lightning activity at locations with specific relief characteristics.

\subsection{Assessment of Lightning Hazards}

Based on the (FFD), the expected frequency of dangerous events for more than 30 thousand buildings in the city of Salzburg could be estimated. The technical standard (EN62305-2 Risk Management) used for the implementation distinguishes between four hazard categories [5]:

$\mathrm{N}_{\mathrm{D}} \quad$ Number of dangerous events due to direct flashes to the structure

$\mathrm{N}_{\mathrm{M}} \quad$ Number of dangerous events due to flashes near the structure (to the ground or the neighbored structure)

$\mathrm{N}_{\mathrm{L}}$ Number of dangerous events due to direct flashes to a service connected to the structure

$\mathrm{N}_{\mathrm{I}}$ Number of dangerous events due to flashes near a service connected to the structure

For reasons of data availability, the proposed approach is restricted to the $\mathrm{N}_{D}$ and $\mathrm{N}_{M}$, whereby $\mathrm{N}_{D}$ was evaluated according to the following equation [5]:

$N_{D}=N_{g} \cdot A_{d} \cdot C_{d} \cdot 10^{-6}$

The estimated hazard potential for buildings caused by direct lightning strikes $\mathrm{N}_{\mathrm{D}}$ was calculated considering the FFD $\left(\mathrm{N}_{\mathrm{g}}\right)$, the so-called equivalent collective area $\mathrm{A}_{\mathrm{d}}$ and a location factor $\mathrm{C}_{\mathrm{d}}$.

For the calculation of $A_{d}$, cadastral data including building heights was utilized. Thereby, the area of $A_{d}$ depends on the height $(\mathrm{H})$ of the building (see Fig. 3).

In addition to lightning density and collective area, a third parameter $C_{d}$ indicating the heights of the surrounding objects was considered. According to EN62305-2 Risk Management [5], four neighborhood dependent constants were foreseen (see Table $\mathbf{1}$ ).

These constants could be evaluated using a detailed digital elevation model (cell size $10 \mathrm{~m}$ ) and building heights, which are based on the cadastral records. Thereby, the influence of objects not included in the cadastral dataset (e.g. trees or power poles) wasn't considered due to the lack of additional data.
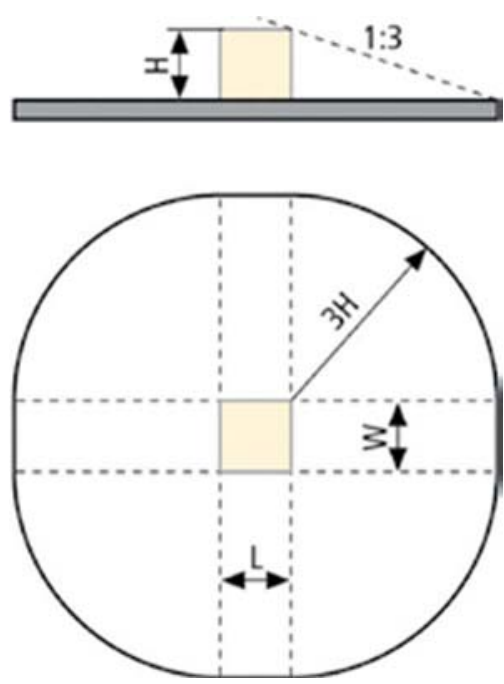

Fig. (3). Collective area $A_{d}$ for direct lightning strikes to buildings [5].

Table 1. Relative Location Constant Cd [5]

\begin{tabular}{|l|c|}
\hline \multicolumn{1}{|c|}{ Relative Location } & $\mathbf{C}_{\mathbf{d}}$ \\
\hline \hline Object is surrounded by higher objects or trees & 0.25 \\
\hline Objects is surrounded by lower objects or trees & 0.5 \\
\hline No other objects within the collective area & 1 \\
\hline Detached object on a hilltop & 2 \\
\hline
\end{tabular}

In addition to the impact of direct lightning strikes to buildings $\left(\mathrm{N}_{\mathrm{D}}\right)$, lightning strikes nearby buildings $\left(\mathrm{N}_{\mathrm{M}}\right)$ can also cause damages due to electromagnetic induction. Hazards of this category $\left(\mathrm{N}_{\mathrm{M}}\right)$ were estimated by means of the following equation [5]:

$N_{M}=N_{g} \cdot A_{m} \cdot 10^{-6}$

Equation 2 contains the variables $\mathrm{N}_{\mathrm{g}}$ and $\mathrm{A}_{\mathrm{m}}$, which represent the FFD and the collective area for indirect lightning strikes. In contrast to the building height dependent area of $A_{d}$ (see Fig. 3), the distance delimitating the border line of $A_{m}$ is indicated by a constant of $250 \mathrm{~m}$ for each building. To uncouple hazards due to direct flashes to structures $\mathrm{N}_{\mathrm{D}}$, the neighborhood dependent collective area $\left(A_{d} \cdot C_{d}\right.$ : cf. equation 1) was subsequently subtracted from the $\mathrm{A}_{\mathrm{m}}$ polygon area.

The inverse values of $N_{D}$ and $N_{M}$ serve as a generally understandable measure for the expected frequency of dangerous events (e.g. 1 event / x years). In order to ensure data privacy protection and smooth existing inaccuracies, the results were interpolated using spatial interpolation techniques for visualization purposes.

In the following section, the estimated hazard surfaces are presented in conjunction with lightning density maps and some generic lightning statistics. 


\section{RESULTS}

\subsection{Spatial Lightning Distribution}

From 1998 to 2009, the lightning detection network EUCLID registered roughly 1 million cloud-to-ground lightning flashes in the federal province of Salzburg and south-east Bavaria. The mean annual density was 2.24 flashes per $\mathrm{km}^{2}$ in the entire study area, 2.35 in Salzburg and 2.06 in south-east Bavaria respectively (see Table 2 compare Fig. (5) for an overview of the study area).

Table 2. Lightning Key Figures in the Study Area (19982009)

\begin{tabular}{|c|c|c|}
\hline & CG Flashes 1998-2009 & Flash Density $\left[\mathbf{k m}^{-2} \cdot \mathbf{a}^{-\mathbf{1}}\right]$ \\
\hline \hline Study Area & 1076151 & 2.24 \\
\hline Salzburg & 201750 & 2.35 \\
\hline $\begin{array}{c}\text { South-east } \\
\text { Bavaria }\end{array}$ & 129104 & 2.06 \\
\hline
\end{tabular}

The lightning density maps show a high cloud-to-ground lightning density variance due to varying thunderstorm activity and tracks. It has to be mentioned, however, that the variance strongly depends on the applied calculation method. Using the LFD method, mean annual densities from 0.25 to 26.00 lightning flashes per $\mathrm{km}^{2}$ occurred. Thereby, the peaks were coincident with elevated objects such as mountains or broadcasting towers. The maximum values (Table 3) may also be a caused by upward-initiated lightning by elevated objects [7]. In contrast, the calculation of the FFD led to a smoother density surface, whereas the PFD exhibited outliers similar to the results obtained with the LFD method (see Table 3).

Table 3. Minimum and Maximum Lightning Densities $\left[\mathrm{km}^{-}\right.$ $\left.2 \cdot a^{-1}\right]$

\begin{tabular}{|c|c|c|}
\hline & Minimum & Maximum \\
\hline \hline LFD & 0.25 & 26.00 \\
\hline FFD & 0.73 & 6.37 \\
\hline PFD & 0.57 & 22.53 \\
\hline
\end{tabular}

Because of its reliability and the widespread use of the FFD method, this method was chosen for further spatial analyses and for the visualization of the perennial lightning activity (1998-2009) in the study area (see Fig. 4).

Areas with extraordinarily high lightning activity were observed on two mountaintop towers: One near the city of Salzburg (Gaisberg) and another nearby Kitzbühel (Kitzbüheler Horn). At these two locations, upward initiated lightning also plays an important role [7]. Further areas of high lightning activity are located across the northern edge of the Alps between the districts Pinzgau and Tennengau.

To quantify regional lightning Cold Spots and Hot Spots respectively, grid cells with a yearly FFD above or below the yearly average FFD in each single investigated year (19982009) were extracted and cartographically conditioned (cf. chapter 2.2). Fig. (5) shows the spatial distribution of these clusters within the study area. Thereby, Hot Spots are mainly located along the northern edge of the Alps and the southeastern part of the considered area, whereas Cold Spots primarily occur in the north and west with an extended Cold Spot spanning the border area between Salzburg and Tyrol. It should be mentioned in this context, that the majority of the areas with increased lightning activity are located along unsettled mountain ridges. The settled area exhibits a relatively low mean FFD of about 2 flashes per $\mathrm{km}^{2}$, since settlements are mainly located along the valley floors.

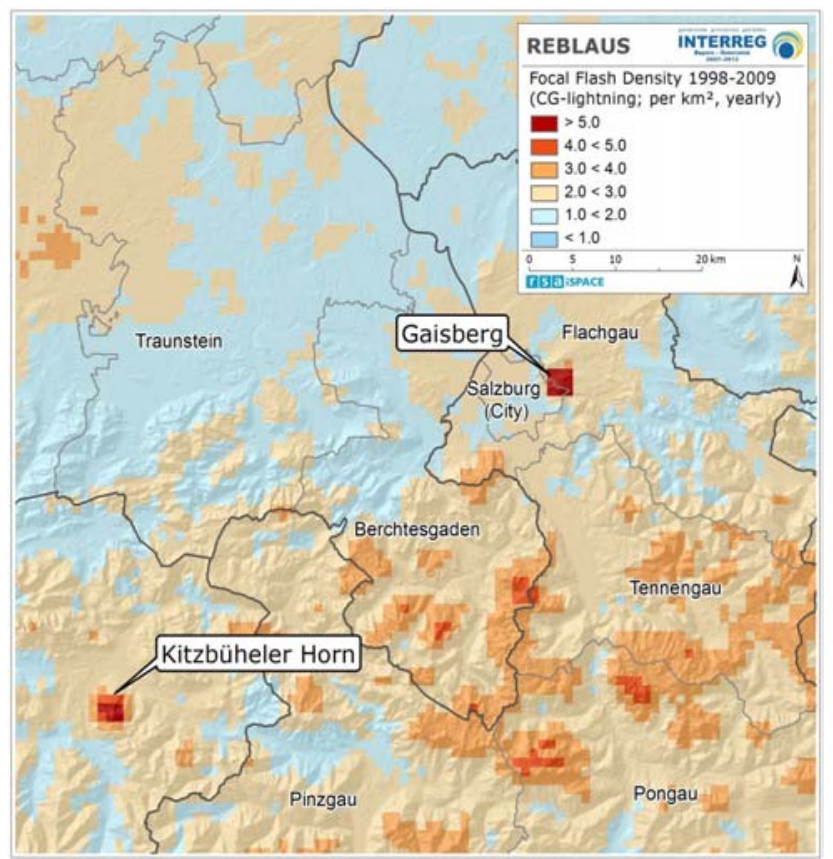

Fig. (4). Focal flash density map of the border area between Salzburg and south-east Bavaria (1998-2009).

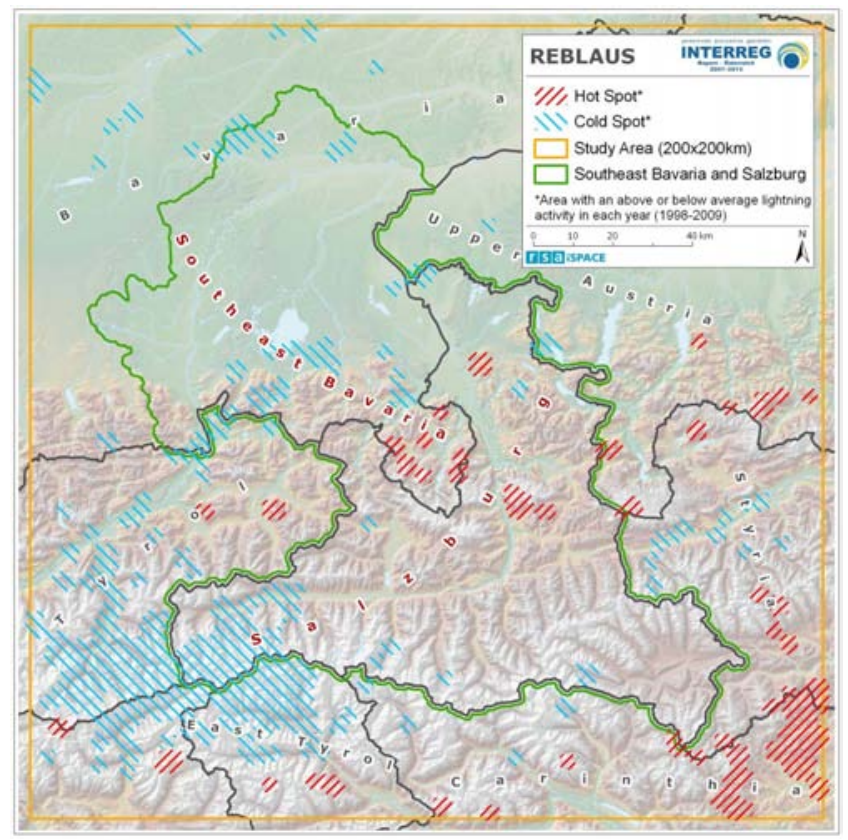

Fig. (5). Lightning Cold Spots and Hot Spots in the study area.

Because of the visualized lightning patterns, it seemed likely that the lightning activity exhibits a certain height 
dependency (see Fig. 4). Fig. (6) shows a surface diagram indicating height and daytime distribution of the lightning activity in the study area.

The effects of daytime on the lightning activity are very clear, whereas height dependency is not linear in this representation. An increase in altitude leads to a higher activity until the culmination point (around 1800 m.s.l.) is reached.

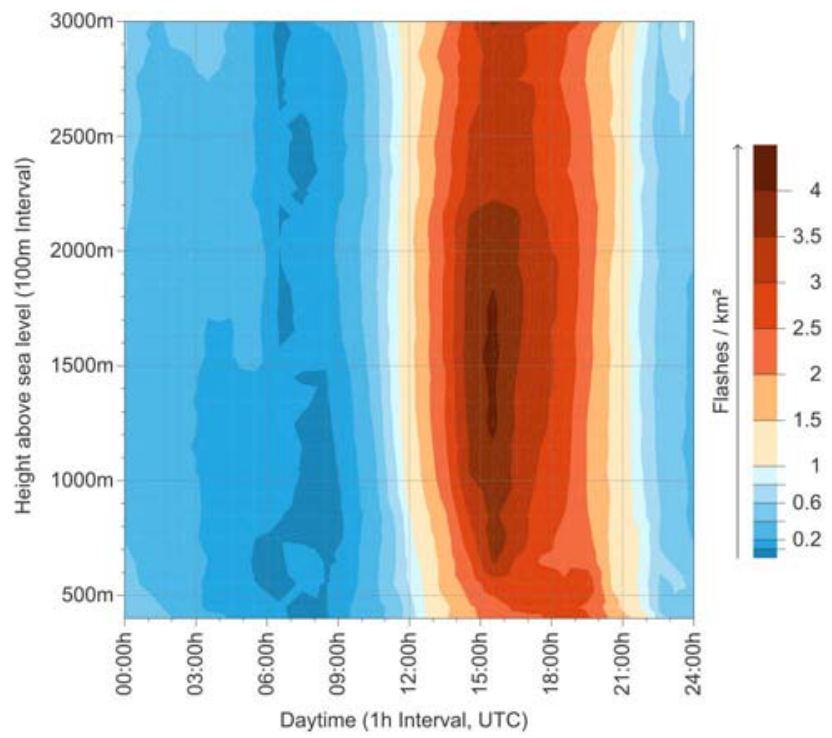

Fig. (6). Height and daytime dependency of the lightning activity in the study area (time period 1998-2009).

The coherence between lightning activity and altitude could be quantified based on an ordinary least square regression. The assumption of a strong positive effect (higher lightning activity with increasing altitude) could be confirmed for the districts Berchtesgaden and Tennengau (compare Fig. 4), which exhibited a squared Pearson coefficient $\left(\mathrm{R}^{2}\right)$ of 0.56 and 0.49 respectively. In contrast, no significant effect was found for the entire study area $\left(\mathrm{R}^{2}=0.096\right)$. A possible explanation could be that the relief characteristics strongly vary across the study area. Regions with a relatively low difference in altitude such as the alpine foothills in the northern part of the study area didn't show any height dependency.

In order to examine this effect in detail, the study area was decomposed into $10 \times 10 \mathrm{~km}$ units, which could be classified according to their relief characteristics. Fig. (7) shows the slope of the linear regression (flash density on altitude) on the $\mathrm{X}$-axis and the range of altitude on the $\mathrm{Y}$ axis for each analysis unit. The point cloud clarifies that relatively flat analysis units reveal both negative and positive regression slopes, whereas units with a high range in altitude mainly exhibit a positive correlation between lightning activity and altitude.

In addition to the height dependence of lightning discharges, the effect of the topographical curvature on lightning patterns was analyzed. Fig. (8) shows the focal flash densities for concave, convex and plane relief features.

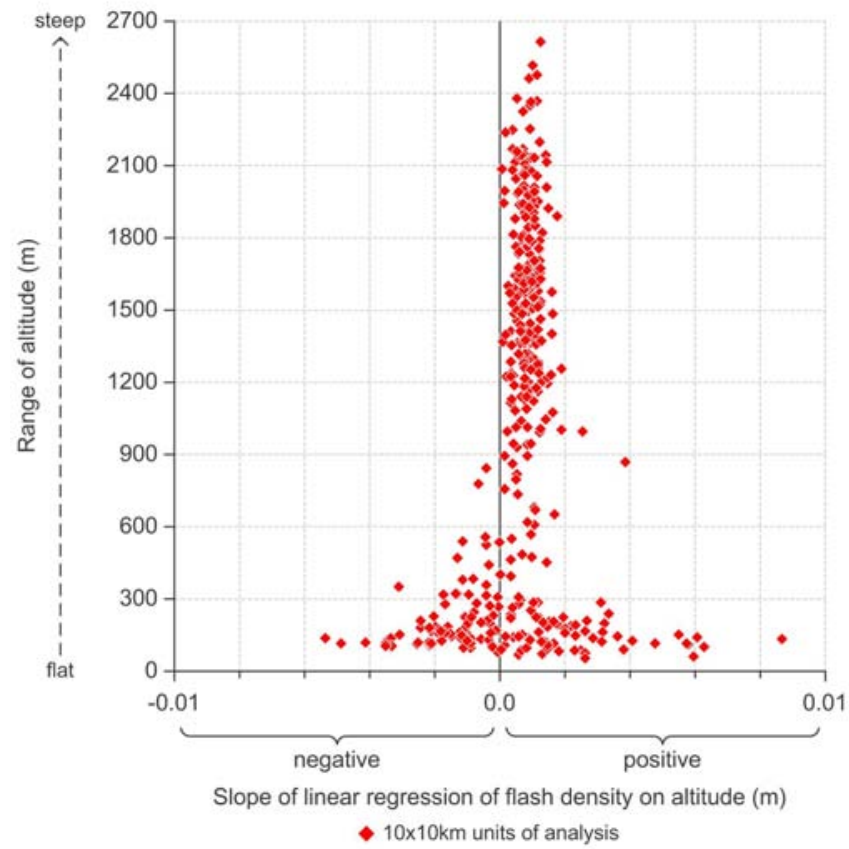

Fig. (7). Slope of linear regression (flash density on altitude) and range of altitude for each analysis unit $(10 \times 10 \mathrm{~km})$.

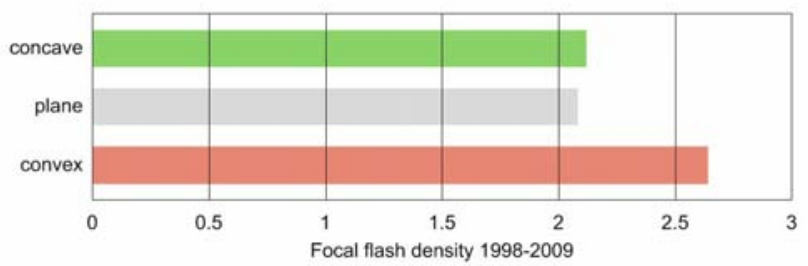

Fig. (8). Focal flash density (1998-2009) and curvature.

Concave valleys and the relatively plane alpine foothills reveal lower lightning activity than convex mountaintops or ridges. Nevertheless, due to the dense settlement in the lowlands and valleys, a relatively low lightning density can lead to high damage rates.

\subsection{Lightning Hazard}

The Austrian Insurance Association (VVO) registered 638 cases of lightning damage in the city of Salzburg in seven years (2002-2008) (predominantly private damage). This damage can be attributed to 1096 cloud-to-ground lightning flashes detected for this timespan within the settlement area of the city. Due to different lightning and settlement densities or building structures the damage distribution is not uniform.

This also applies for the calculated hazard distribution which shows the expected frequency of hazardous events.

The result for the hazard category $\mathrm{N}_{\mathrm{D}}$ is shown in Fig. (10) and for $\mathrm{N}_{\mathrm{M}}$ in Fig. (11). Their underlying lightning flash record between 1998 and 2009 (FFD 1998-2009) is shown in Fig. (9). The results illustrate an extraordinary higher hazard due to electromagnetic induction (up to one event in each year). In contrast, hazards caused by direct lightning strikes occur very rarely (every 10 to 2200 years). 
However, not each hazardous event necessarily causes damage.

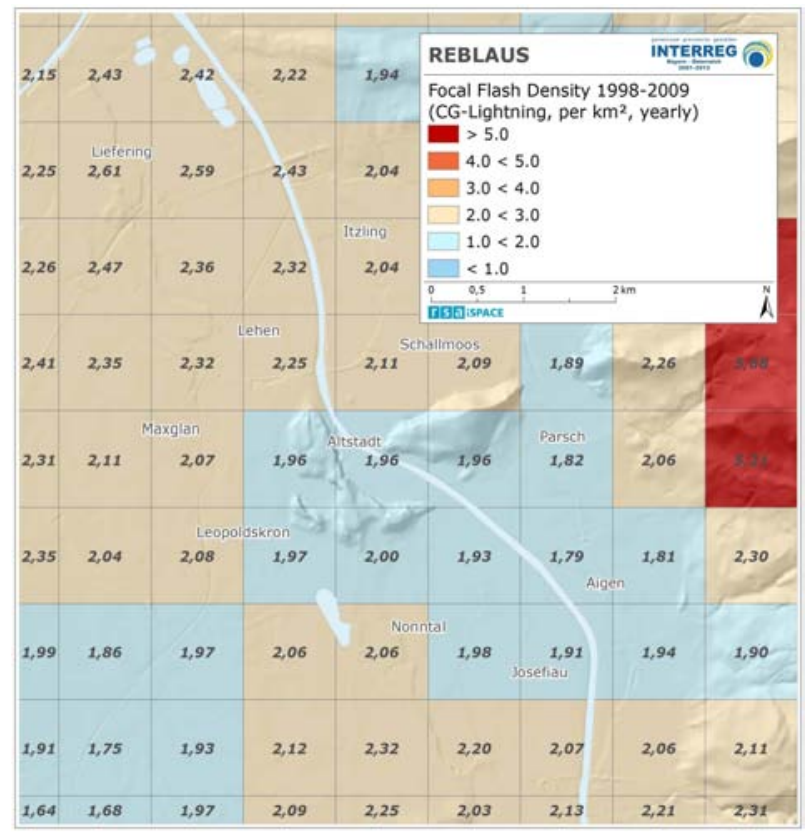

Fig. (9). Focal flash density FFD 1998-2009 (city of Salzburg).

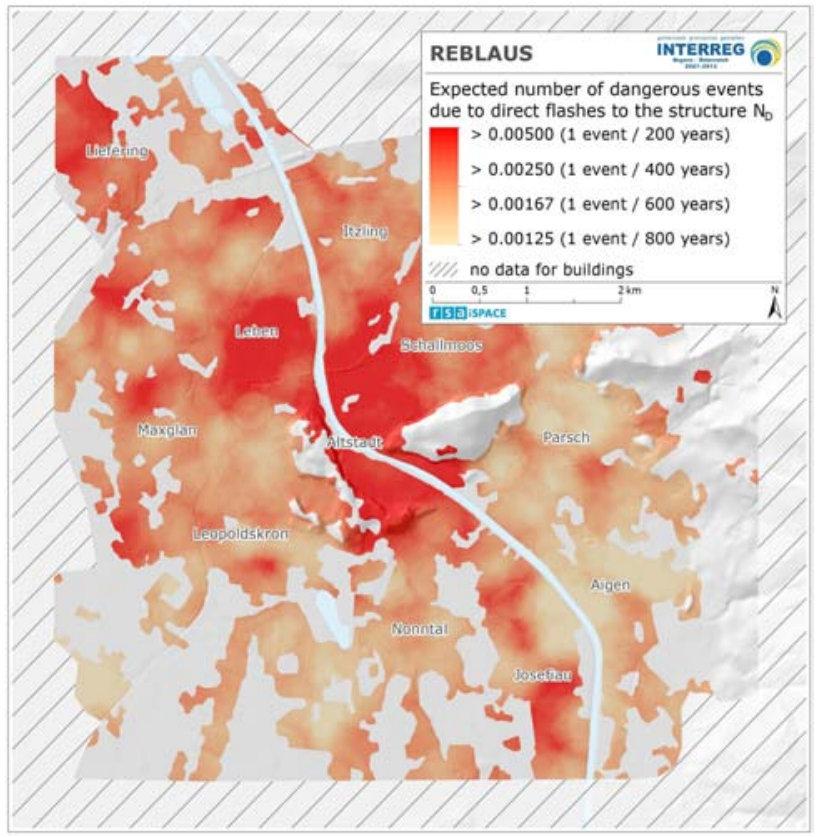

Fig. (10). Interpolated surface for the expected number of dangerous events due to direct flashes to the structure $\mathrm{N}_{\mathrm{D}}$ (city of Salzburg).

The values in Fig. (10) primarily depend on the building height. In contrast, Fig. (11) exhibits patterns similar to the FFD grid shown in Fig. (9). Small-scale peaks mainly correspond to extensive buildings such as the fortress or the university building (Fig. 11).

The comparison of Fig. (10) and Fig. (11) shows, that for estimating the expected number of hazardous events caused by electromagnetic induction $\left(\mathrm{N}_{\mathrm{M}}\right)$ primarily the existing $\mathrm{CG}$ lightning density (FFD, see Fig. 9) is responsible, since building heights do not have any influence (cf. equation 2). For direct lightning strikes $\mathrm{N}_{\mathrm{D}}$ the parameters building size and height explain the variability of the result.

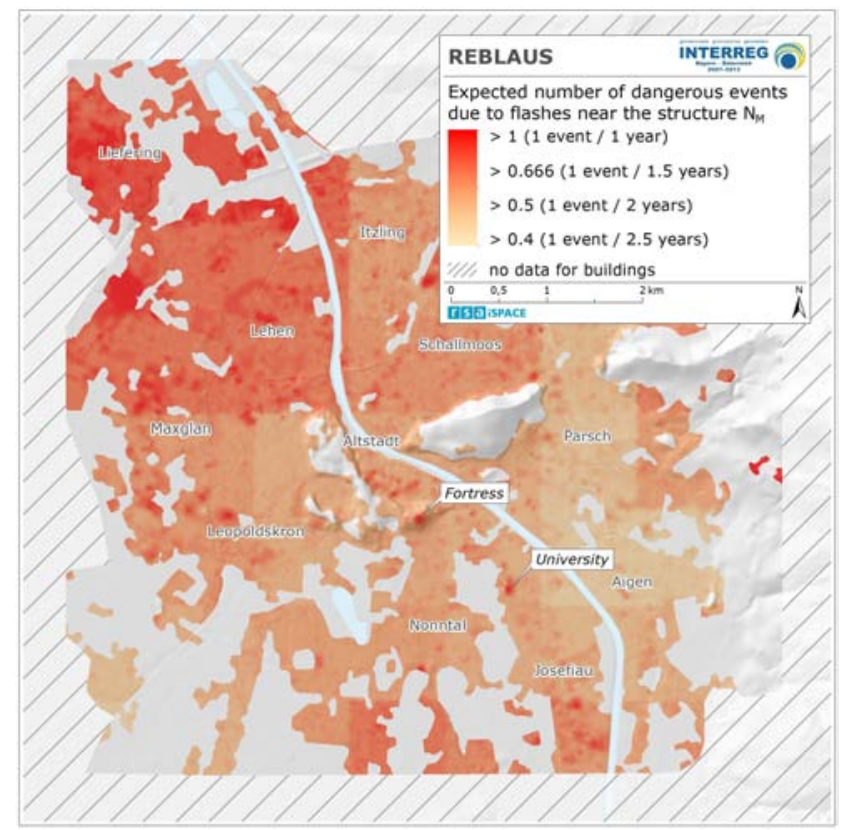

Fig. (11). Interpolated surface expected number of dangerous events due to flashes near the structure $\mathrm{N}_{\mathrm{M}}$ (city of Salzburg).

In the following section possible reasons for these spatial structures are discussed in more detail.

\section{CONCLUSION}

One main outcome of the study was an up-to-date knowledge base about regional lightning distributions. The derived density maps made it possible to capture lightning Cold and Hot Spots. Extensive Hot Spots were found along the northern edge of the Alps and the south eastern part of the investigated area, whereas Cold Spots mainly occurred in the west. It has to be mentioned, however, that these areas don't represent a sharp delimitation, since they are a cartographic representation. Because of the spatially and temporally discontinuous characteristic of the lightning process, heavy thunderstorms can also appear at locations which exhibited low lightning activity within the twelve years considered in this study. Nevertheless, a web-based implementation as a decision support for spatial planning and risk management purposes can be envisaged (e.g. HORA [2]: Natural Hazard Overview \& Risk Assessment Austria). In this regard, the spatially disaggregated database enables policy-makers to assess hazard probabilities and react to them in an appropriate manner, as well as to increase public awareness of lightning hazard.

Moreover, based on the density maps, various calculations regarding the coherence between lightning activity and altitude could be made. Thereby, high positive correlations were found in the districts Tennengau and Berchtesgaden. In general, the correlations strongly depended on the relief of the considered region. Areas with quite small differences in altitude, such as the foothills in the north, showed very low positive or even negative correlations, whereas mountainous regions tended to positive 
correlations. In addition, the assumption of high lightning activities at convex mountaintops or ridges could be confirmed. In contrast, concave and plane topographic structures showed lower lightning densities.

The lightning density is fundamental for the estimation of lightning hazards to buildings in the city of Salzburg. The results showed that hazardous events due to induction are more probable than direct strikes. The main reason for this result is the large reach of lightning discharges according to the collective area envisaged by the European lightning protection standard (EN62305-2 Risk Management [5]). Depending on building density, distances of up to $700 \mathrm{~m}$ between the location of the lightning flash and the location of damage were observed [8]. The usage of a constant of $250 \mathrm{~m}$ for each building led to a mitigation of the importance of this parameter. Thus, the lightning density seems to be the essential factor when estimating the distribution of lightning hazards due to electromagnetic induction. In contrast, the relatively high hazard potential for direct lightning strikes obtained for buildings near the city center reveal an obvious coherence with the settlement structure. High buildings attract lightning flashes and therefore face a higher hazard.

However, the GIS-based usage of this approach currently suffers from several limitations. Trees or the complex architectures of buildings, which influence hazard potentials, cannot be considered. In order to avoid inaccuracies due to the simplification of the digital representation of the surface, the usage of high resolution laser scan datasets could be envisaged.

Nevertheless, the GIS technologies used to aggregate and analyze the detected cloud-to-ground lightning flashes provide powerful tools for handling spatial data. By means of calculating and comparing different density aggregation methods, valuable insights regarding their implementation with Geographic Information Systems could be gained. One major advantage of the PFD is the consideration of detection inaccuracies, which enables a more realistic estimation of lightning densities. In order to use this innovative method for large-scale risk analyses, however, further research in regard to the validation of the implementation will be necessary.

\section{ACKNOWLEDGEMENTS}

This paper is based on the European Union funded INTERREG IV A - project "cross-border risk and natural hazard management based on regional lightning analyses" (German abbreviation "Reblaus [10]). Project and Funding
Partners: Research Studio iSPACE; Austrian Lightning Detection \& Information System (ALDIS); Max-PlanckInstitute for Plamsa Physics; Austrian Insurance Association; Austrian Federal Ministry of Agriculture, Forstry, Environment and Water Management; Bavarian State Ministry of the Environment and Public Health; City of Salzburg. Project Supporters: Government office of Land Salzburg; EuRegio Salzburg - Berchtesgadener Land Traunstein.

This research was partially funded by the Austrian Science Fund (FWF) through the Doctoral College GIScience (DK W 1237-N23).

\section{CONFLICT OF INTEREST}

The authors confirm that this article content has no conflicts of interest.

\section{REFERENCES}

[1] Allianz Insurance Group. Presse Information. Allianz gibt Tipps gegen Blitzschäden. Available at: http://www.ots.at/presseausse ndung/OTS_20060726_OTS0027 (08.05.2012).

[2] HORA. Natural Hazard Overview and Risk Assessment Austria Available at: http://www.hora.gv.at (08.05.2012).

[3] Kuleshov Y, Mackerras D, Darvenizla M. Spatial distribution and frequency of thunderstorms and lightning in Australia. In: Betz HD, Schumann U, Laroche P, Eds. Lightning: principles, instruments and applications. Review of modern lightning research. USA: Springer 2009; pp. 187-207.

[4] Diendorfer G. Some comments on the achievable accuracy of local ground flash density values. In: Conference proceedings. 29th International Conference on Lightning Protection 2008.

[5] Kern A, Landers UL, Diendorfer G. Die neue österreichische Blitzschutznormung (2). Available at: http://www.aldis.at/Blitzschu tz/Blitzschutznorm_Teil2_EJ7_08.pdf (08.05.2012).

[6] Campos D, Pinto O. Investigation about the intensity and location of the maximum cloud-to-ground lightning flash density in the city of Sao Paolo. Available at: http://ws9.iee.usp.br/sipdax/papersix/ sessao02/2.12.pdf (08.05.2012).

[7] ALDIS. Forschungsprojekt Gaißberg. Available at: http://www.ald is.at/forschung/projekte.html

[8] Kern A, Dikta G, Krichel F. Hilfestellung zur einfacheren Beurteilung von Blitz- und Überspannungsschäden in der Schadensregulierung, Endbericht, Studie im Auftrag des Gesamtverbandes der Deutschen Versicherungswirtschaft (GDV). Available at: http://www.elab-juelich.de/Kern/Forschungsprojekte/ p3/Studie_FH_Aachen.pdf (08.05.2012).

[9] Diendorfer G. Lightning Location Systems (LLS), In: IX International Symposium on Lightning Protection 2007.

[10] Prinz T. Grenzübergreifendes Risiko- und Naturgefahrenmanagement durch Regionalisierte Blitzauswertung (Reblaus). Available at: http://www.reblaus-interreg.eu (08.05.2012). 